\title{
Biological aspects of Tiracola grandirena (Herrich-Schäffer, 1868) (Lepidoptera: Noctuidae): a polyphagous armyworm
}

\author{
Specht, A. ${ }^{\mathrm{a}, \mathrm{b} *}$, Iltchenco, J. ${ }^{\mathrm{b}}$, Fronza, E. ${ }^{\mathrm{b}}$, Roque-Specht, $V F^{\mathrm{c}},{ }^{\mathrm{c}}$ Luz, PC. ${ }^{\mathrm{b}}$ and Montezzano, DG. ${ }^{\mathrm{b}}$ \\ aLaboratório de Entomologia, Embrapa Cerrados, BR 020, Km 18, CP 08223, CEP 73310-970 Planaltina, DF, Brazil \\ 'Programa de Pós-graduação em Biotecnologia, Centro de Ciências Agrárias e Biológicas, Universidade de \\ Caxias do Sul - UCS, CP 1352, CEP 95070-560, Caxias do Sul, RS, Brazil \\ 'Faculdade UnB Planaltina, Universidade de Brasília - FUP/UnB, Área Universitária n. 1, Vila Nossa Senhora de Fátima, \\ CEP 73345-010, Planaltina, DF, Brazil \\ *e-mail: alexandre.specht@embrapa.br
}

Received: July 4, 2012 - Accepted: November 27, 2012 - Distributed: February 28, 2014

\begin{abstract}
We studied the biology of Tiracola grandirena (Herrich-Schäffer, 1868) (Lepidoptera: Noctuidae: Hadeninae) at $25 \pm 1{ }^{\circ} \mathrm{C}, 70 \pm 10 \% \mathrm{RH}$ and 14 hours of photo phase. Three experiments, using 150 larvae each, were conducted for the larval stage. In the first, used to assess the duration and survival of all stages, insects were reared individually and fed an artificial diet (Grenee). In the second, individuals were also reared separately, but were fed leaves of 10 plants from different families. In the third, the larvae were not individualised, the food plants were rotated such as to provide three plant species every 48 hours. In the first experiment, the viability of the eggs, larvae, pupae and prepupae was $91.9,94.7,32.49$ and $43.5 \%$, respectively. The average duration of the egg, larvae, prepupae, pupae and adult were 6.0, 25.3, 25.7, 21.4 and 12.7 days, respectively. The prolonged prepupal period indicates that $T$. grandirena can develop larval (prepupal) diapause. The results of the experiments with different host plants showed that $T$. grandirena is polyphagous at species, population and individual level.
\end{abstract}

Keywords: caterpillar, developmental biology, prepupal diapause, Hadeninae.

\section{Aspectos biológicos de Tiracola grandirena (Herrich-Schäffer, 1868) (Lepidoptera: Noctuidae): uma lagarta polífaga}

\section{Resumo}

Estudou-se a biologia de Tiracola grandirena (Herrich-Schäffer, 1868) (Lepidoptera: Noctuidae: Hadeninae) em condições controladas de $25 \pm 1{ }^{\circ} \mathrm{C}, 70 \pm 10 \%$ UR e fotofase de 14 horas. Na fase larval foram estabelecidos três experimentos empregando 150 larvas cada. No primeiro, os insetos foram criados individualmente, com dieta artificial de Grenee, cujos dados foram utilizados para avaliar a duração e a sobrevivência das larvas, pupas e adultos. No segundo, as larvas foram criadas individualmente, alimentadas com folhas de 10 plantas de famílias diferentes avaliando-se a sobrevivência e duração larval (fase ativa). No terceiro, as larvas foram mantidas em um mesmo recipiente, variando-se a alimentação vegetal, três espécies a cada 48 horas, avaliando-se apenas a sobrevivência larval. No primeiro experimento a viabilidade de ovo, larva, pré-pupa e pupa foi de 91,$93 ; 94,67 ; 32,39$ e 43,48\%, respectivamente. A duração média de ovo, larva, pré-pupa, pupa e adulto foi de 6,$00 ; 25,26 ; 25,76 ; 21,35$ e 12,67 dias, respectivamente. O prolongado período de pré-pupa indicou que, nas condições em que foi criada $T$. grandirena pode desenvolver diapausa larval (pré-pupal). Os resultados dos experimentos com diferentes plantas hospedeiras demonstraram que $T$. grandirena é polífaga ao nível específico, populacional e individual.

Palavras-chave: lagarta, biologia do desenvolvimento, diapausa prepupal, Hadeninae.

\section{Introduction}

Tiracola Moore, 1881 is cosmopolitan and includes only 10 species (Poole, 1989). Tiracola grandirena (HerrichSchäffer, 1868) is the most widely distributed species in the Americas, occurring in countries such as Mexico, Cuba, Jamaica, Puerto Rico, Costa Rica, Venezuela and Brazil (Todd and Poole, 1980; Specht and Corseuil, 2001; Becker, 2002; Specht et al., 2004). The species has been confused with T. plagiata (Walker, 1857) (e.g. Specht and Corseuil, 2001; Specht et al., 2004) because of intraspecific variation in colour, which also motivated Draudt (1924) to describe two varieties, magniplaga and mediosuffusa. In the Northern Hemisphere, the distribution of T. grandirena is restricted to the 20th parallel (between the towns of Jalapa, Cordoba and Misantla, Mexico) (Becker, 2002), 
whereas in the Southern Hemisphere it reaches parallel 30, in Pelotas, Rio Grande do Sul, Brazil (Specht et al., 2004).

The main biological parameters of $T$. grandirena are unknown. The species has been reported on 36 host plants belonging to 19 families (Janzen and Hallwachs, 2009). Additionally, Bruner et al. (1945) reported on larvae attacking coffee in Cuba, and Specht et al. (2004), using unpublished data from Biezanko, indicated that larvae of T. grandirena were attacking Jasmine-Blue (Plumbago capensis Thunb. - Plumbaginaceae) in Pelotas.

Considering the lack of knowledge about the biology of $T$. grandirena, a polyphagous species, combined with the damage caused by $T$. plagiata on crops of economic interest such as bananas, cocoa, tobacco, orange, castor, cassava and sisal (e.g. Robinson, 1975) in the Eastern Hemisphere, this study aimed to evaluate the main biological parameters of $T$. grandirena under controlled conditions.

\section{Material and Methods}

Laboratory rearing started with 2,156 eggs from a female collected in Anta Gorda, state of Rio Grande do Sul, Brazil (28 56' 40,8' S; 52 01' 12,4" W; 545 m height), on October 10, 2010. All experiments were performed under controlled conditions $\left(25 \pm 1{ }^{\circ} \mathrm{C}, 70 \pm 10 \% \mathrm{RH}\right.$ and photo phase of 14 hours).

The main biological parameters were obtained from 150 larvae fed an artificial diet. Two other experiments, also employing 150 larvae each, assessed the species and individual polyphagy of $T$. grandirena.

\subsection{Biological parameters}

We evaluated the viability and duration of the embryonic period of all eggs laid by the female collected in the field. Each egg mass was individualised in a Petri dish and separated from the others by date. The bottom of the dish was lined with filter paper, which was moistened with distilled water until the larvae hatched.

The survival and duration of larval development of individuals fed an artificial diet (Greene et al., 1976) were evaluated. The following parameters were measured: duration of larval stages, in days; total duration of the period during which the larvae remained in activity and feeding; duration of the prepupal period, during which the larvae stop feeding, becoming inactive and decrease in size until metamorphosis. Due to the fact that larvae bury themselves in the soil to construct the pupal chamber, we added expanded vermiculite, moistened with distilled water to each container at the beginning of the prepupal period. We measured the widest portion of the cephalic capsules of the first and last instars in order to compare our measurements with those from other noctuids. Additionally, we measured the distance between the frontal setae (Podoler and Klein, 1978) of ten larvae which metamorphosed into adults, in order to evaluate their growth rates and whether growth rates fit the linear model of Dyar (1890).

The pupae were kept under the same conditions and containers as the prepupae. On the second day after pupation, when the insects' cuticle was hardened, we ascertained the sex of each individual using the sketches of Angulo et al. (2008). In addition to duration of the pupal stage, we evaluated the weight, length and greater width between pterotecae.

Because it was difficult to obtain adults of both sexes simultaneously, we used only data from the female collected in the field to assess fecundity and fertility. Consequently, we did not have access to emergence data. In order to estimate longevity, we observed three virgin females which had emerged in the laboratory. The adults were kept in cylindrical plastic containers with the following dimensions: $10 \mathrm{~cm}$ diameter and $15 \mathrm{~cm}$ height; the top of the container was closed with a plastic film. Animals were fed a liquid diet (Hoffmann-Campo et al., 1985) offered in a cotton wool swab.

\subsection{Evaluation of polyphagy at specific level}

In order to evaluate the degree of polyphagy of $T$. grandirena, we followed the development of 15 individualised larvae which were offered ten plant species from different families. The following potential hosts were offered to the larvae: Schinus terebenthifolium Raddi - Anacardiaceae [St], Musa paradisiaca Linn. var. sapientum Kuntze - Musaceae [Mp], Nectandra megapotamica (Spreng.) Mez. - Lauraceae [Nm], Diospyros kaki L. - Ebenaceae [Dk], Schefflera arboricola Hayata - Araliaceae [As], Tabebuia umbellata (Sond.) Sandwith - Bignoniaceae [Tu], Citrus sinensis (Linn.) Osbeck Rutaceae [Cs], Malus domestica Borkhausen - Rosaceae [Md], Ricinus communis Linn. - Euphobiaceae [Rc] and Platanus acerifolia (Aiton) Willd. - Platanaceae [Pa]. The leaves were changed daily. In order to ensure that leaves remained turgid, we immersed their petioles or basal portions in a $20 \mathrm{ml}$ Erlenmeyer flask glass filled with distilled water. In the beginning of the prepupal period the larvae escaped from the glasses, looking for a place to form the pupal chamber. Most larvae hid throughout the room and died, making it impossible to continue the experiment. Consequently, only the survival and duration of the larval stage were evaluated in this experiment. The average results were compared using the Tukey test with a $5 \%$ confidence level.

\subsection{Evaluation of polyphagy at individual level}

In order to ascertain individual polyphagy, we evaluated the survival of larvae kept in a glass box $(30 \times 40 \times 60 \mathrm{~cm})$, changing the host plants (three plant species), every two days. Host plants were offered in the following order: $\{\mathrm{St}, \mathrm{Mp}, \mathrm{Nm}\},\{\mathrm{Dk}, \mathrm{As}, \mathrm{Tu}\},\{\mathrm{Cs}, \mathrm{Md}, \mathrm{Rc}\},\{\mathrm{Pa}, \mathrm{St}, \mathrm{Mp}\}$, $\{\mathrm{Nm}, \mathrm{Dk}, \mathrm{The}\},\{\mathrm{Tu}, \mathrm{Cs}, \mathrm{Md}\},\{\mathrm{Rc}, \mathrm{Pa}, \mathrm{St}\},\{\mathrm{Mp}, \mathrm{Nm}, \mathrm{Dk}\}$, $\{\mathrm{As}, \mathrm{You}, \mathrm{Cs}\}\{\mathrm{Md}, \mathrm{Rc}, \mathrm{Pa}\},\{\mathrm{St}, \mathrm{Mp}, \mathrm{Nm}\},\{\mathrm{Dk}, \mathrm{As}, \mathrm{Tu}\}$, $\{\mathrm{Cs}, \mathrm{Md}, \mathrm{Rc}\},\{\mathrm{Pa}, \mathrm{St}, \mathrm{Mp}\},\{\mathrm{Nm}, \mathrm{Dk}, \mathrm{As}\}$. In this experiment, branches of each of the three plants were offered in $150 \mathrm{ml}$ glass Erlenmeyer flasks, which were placed in the box, to ensure that larvae could migrate to the newly offered plants. After 24 hours, the jars with the older food-plants were removed and the larvae still on them were carefully removed and transferred to the new 
plants. We assessed larval survival (\%) only until they left their plant, indicating the beginning of the prepupal period.

The temporal and morphometric parameters were analysed using descriptive statistics with the calculation of means and standard errors. Means were compared by t -test assuming unequal variances at a significance level of $95 \%$.

We compared the various biological parameters of T. grandirena with those of a closely-related species, T. plagiata. Data for the latter were taken from Temperley (1930) and Catley (1963), who had performed laboratory and field experiments without indicating the temperature, humidity and photoperiod. Where appropriate, our results were also compared with data from other noctuids reared under similar conditions.

\section{Results}

\subsection{Biological parameters}

The viability of eggs from females collected in the field, was high (Table 1) and the incubation period corresponded to $6.6 \%$ of the life cycle.

All larvae underwent six instars and the maximum width of the cephalic capsule and body length of 13 individuals ranged from $0.4 \pm 0.00 \mathrm{~mm}$ and $2.7 \pm 0.09 \mathrm{~mm}$ in the first instar to $4.1 \pm 0.03 \mathrm{~mm}$ and $61.3 \pm 1.81 \mathrm{~mm}$, in last instar, respectively. The distance between the frontal setae (Table 2) revealed an average growth ratio of 1.8 from one instar to the next, with higher values in the first three. The entire larval period of $T$. grandirena corresponded to approximately $56 \%$ of the entire life cycle of the species. However, on average, for more than half of this period, larvae remained inactive as prepupae (Table 1). We also noted that, while the larvae remained active, there was not much variation in the duration of each instar, and in the duration of the entire period stage (22-28 days). However, the longest duration of the prepupal period (57 days) was about five times longer than the shortest (11 days).

After hatching, the larvae completely consumed the egg chorion and did not eat for up to 48 hours, observing that the first instar was longer than the other instars. However, there was a progressive increase in the duration of the instars, from the second instar until the last instar (Table 2).

Survival was high for all active larval instars of T. grandirena. However, in the prepupal period, at least $50 \%$ of the larvae died after 57 days, before metamorphosis. This period was also characterised by great variability in duration. The longest living prepupae survived 128 days and died before metamorphosis (Table 1).

The pupae stage was also characterised by low viability and it lasted nearly one quarter $(23.5 \%)$ of the time required to complete the life cycle (Table 1). The length, width and

Table 1. Survival $(\%)$ and mean $( \pm \mathrm{SE})$ duration, in days, of Tiracola grandirena individuals whose larvae were fed an artificial diet (Greene et al., 1976) under controlled conditions $\left(25 \pm 1{ }^{\circ} \mathrm{C}, 70 \pm 10 \% \mathrm{RH}\right.$ and 14 hours of photo phase).

\begin{tabular}{|c|c|c|c|c|c|c|}
\hline \multicolumn{2}{|c|}{ Developmental } & & \multicolumn{2}{|c|}{ Survival } & \multicolumn{2}{|c|}{ Duration (Days) } \\
\hline \multicolumn{2}{|c|}{ Stage } & Initial (N) & Surviving & $(\%)$ & Mean \pm S.E. & Range \\
\hline \multicolumn{2}{|c|}{ Egg } & 2156 & 1982 & 91.9 & $6.0 \pm 0.00$ & 6 \\
\hline & I & 150 & 148 & 98.7 & $5.9 \pm 0.05$ & $5-7$ \\
\hline $\mathrm{L}$ & II & 148 & 145 & 97.9 & $3.9 \pm 0.03$ & $2-4$ \\
\hline A & III & 145 & 145 & 100.0 & $3.1 \pm 0.04$ & $3-4$ \\
\hline $\mathrm{R}$ & IV & 145 & 145 & 100.0 & $3.7 \pm 0.04$ & $3-5$ \\
\hline $\mathrm{V}$ & $\mathrm{V}$ & 145 & 145 & 100.0 & $4.2 \pm 0.05$ & $3-6$ \\
\hline A & VI* & 145 & 142 & 97.9 & $4.3 \pm 0.05$ & $4-6$ \\
\hline $\mathrm{E}$ & VI** & 142 & 46 & 32.4 & $25.8 \pm 1.13$ & $11-57$ \\
\hline \multicolumn{2}{|c|}{ Pupae } & 46 & 20 & 43.5 & $21.3 \pm 0.65$ & $16-29$ \\
\hline \multicolumn{2}{|c|}{ Adults*** } & 20 & --- & --- & $12.7 \pm 2.45$ & $9-17$ \\
\hline
\end{tabular}

* active sixth instar larva; $* *$ inactive sixth instar larva, in the prepupal period; $* * *$ duration considering only three virgin females.

Table 2. Averages $(n=10)$ of the distances between the frontal setae with the respective standard errors, growth rates and duration of each instar of Tiracola grandirena fed on artificial diet (Greene et al., 1976), under controlled conditions $(25 \pm 1$ ${ }^{\circ} \mathrm{C}, 70 \pm 10 \% \mathrm{RH}$ and photo phase of 14 hours).

\begin{tabular}{|c|c|c|c|}
\hline Instar & $\begin{array}{c}\text { Distance between frontal } \\
\text { setae }(\mathrm{mm})(X \pm \mathrm{SE})\end{array}$ & Growth Rate & Duration (days) \\
\hline I & $0.1 \pm 0.00$ & --- & $6.0 \pm 0.20$ \\
\hline II & $0.2 \pm 0.01$ & 2.0 & $3.9 \pm 0.13$ \\
\hline III & $0.4 \pm 0.01$ & 2.0 & $3.1 \pm 0.14$ \\
\hline IV & $0.7 \pm 0.02$ & 1.7 & $3.7 \pm 0.17$ \\
\hline $\mathrm{V}$ & $1.1 \pm 0.02$ & 1.6 & $4.2 \pm 0.20$ \\
\hline VI & $1.9 \pm 0.04$ & 1.7 & $4.3 \pm 0.17^{*}$ \\
\hline
\end{tabular}

* Active larvae, excluding the prepupal period. 
weight (Table 3 ) of the pupae did not differ significantly between sexes.

The average lifespan of three females of $T$. grandirena which had emerged in the laboratory (Table 1) was 12.7 days. The female of $T$. grandirena collected in the field had almost all the body scales, indicating that not much time had passed since its emergence. It oviposited in the first $(n=234)$, second $(n=367)$, eighth $(n=819)$, ninth $(n=402)$, tenth $(n=231)$ and eleventh days $(n=103)$, and died on the twelfth day after being collected. In the laboratory, T. grandirena eggs were laid in batches and sometimes in layers.

\subsection{Evaluation of polyphagy at species level}

As described for the larvae reared on an artificial diet, those fed different host plants also began to eat after 48 hours. Initially, larvae would just scrape the leaf surface. In subsequent instars, however, they would consume the entire leaf. Larval development was relatively uneven; there were larger and smaller larvae in all treatments. Larvae fed indiscriminately on the offered host plants, and there was practically no mortality until becoming prepupae in the sixth instar. The average larval duration was similar in all treatments without significant differences, but with very pronounced deviations (Table 4).

\subsection{Evaluation of polyphagy at individual level}

In the third experiment, in which the plants were exchanged every 48 hours, it was observed that there was almost $10 \%$ mortality within four days. However the survival rate of the larvae (active period) was $84.0 \%$, demonstrating that $T$. grandirena larvae can easily feed on different host plants during development.

\section{Discussion}

\subsection{Egg stage}

The high viability of this stage (Table 1) was consistent with observations made by Temperley (1930) on eggs from a $T$. plagiata female, also collected in the field. In the latter experiment, even though nearly all the eggs were fertile to begin with, adverse laboratory conditions such as low humidity and mechanical injuries during rearing prevented larvae from hatching. The observations of our study are consistent with field observations in which eggs from females collected in nature, including the first generation, are highly viable (viability percentages above 90\%) (Specht et al., 2008).

The incubation period (Table 1) of T. grandirena was slightly shorter than that observed for $T$. plagiata reared in the laboratory (Temperley (1930) 7.8\%, Catley (1963) $\sim 7.9 \%$ ). The duration of incubation in our experiment approximates that of other noctuids, for instance Pseudaletia sequax Franclemont, 1951 (Buainain and Silva, 1988 5.9\%), Anicla infecta (Ochsenheimer, 1816) (Teston et al. (2001) 6.4\%) and Anicla mahalpa Schaus, 1898 (Specht et al. $(2008) \sim 6.9 \%$ ), reared under similar conditions. The incubation periods of T. grandirena in this work and T. plagiata reared in the laboratory (Temperley, 1930; Catley, 1963) were much longer than in the field (3.5 to 4 days according to Catley (1963)).

Table 3. Means and their standard errors, minimum and maximum length, width and weight of Tiracola grandirena pupae, whose larvae were fed an artificial diet (Greene et al., 1976), under controlled conditions $\left(25 \pm 1{ }^{\circ} \mathrm{C}, 70 \pm 10 \% \mathrm{RH}\right.$ and photo phase of 14 hours).

\begin{tabular}{lcccccc}
\hline \multirow{2}{*}{ Gender (N) } & \multicolumn{2}{c}{ Length $(\mathbf{m m})$} & \multicolumn{2}{c}{ Width $(\mathbf{m m})$} & \multicolumn{2}{c}{ Weight (g) } \\
\cline { 2 - 7 } & $\mathbf{X} \pm \mathbf{S E}$ & Range & $\mathbf{X} \pm \mathbf{S E}$ & Range & $\mathbf{X} \pm \mathbf{S E}$ & Range \\
\hline Female (7) & $25.5 \pm 0.69$ & $22.8-28.1$ & $8.5 \pm 0.22$ & $7.77-9.00$ & $1.0 \pm 0.06$ & $0.8-1.2$ \\
Male (10) & $24.8 \pm 0.48$ & $22.7-26.9$ & $8.6 \pm 0.19$ & $7.62-9.51$ & $0.9 \pm 0.06$ & $0.7-1.3$ \\
$t(\mathrm{p} \mathrm{0.05 \% )}$ & \multicolumn{2}{c}{0.47} & \multicolumn{2}{c}{0.61} & \multicolumn{2}{c}{0.67} \\
Total & $25.1 \pm 0.61$ & $22.7-28.1$ & $8.6 \pm 0.14$ & $7.62-9.51$ & $1.0 \pm 0.05$ & $0.8-1.3$ \\
\hline
\end{tabular}

Table 4. Number of larvae of Tiracola grandirena reaching the sixth instar, percentage survival and duration until the beginning of the prepupal period, considering 15 neonate larvae for each host plant, under controlled conditions $\left(25 \pm 1{ }^{\circ} \mathrm{C}\right.$, $70 \pm 10 \% \mathrm{RH}$ and photo phase of 14 hours).

\begin{tabular}{lrrc}
\hline \multirow{2}{*}{ Host plant } & \multicolumn{2}{c}{ Survival } & Duration (days) \\
\cline { 2 - 4 } & N & \% & Mean Deviation \\
\hline Schinus terebenthifolium - Anacardiaceae & 14 & 93.3 & $25.5 \pm 0.87$ \\
Musa paradisiaca - Musaceae & 15 & 100.0 & $23.6 \pm 1.27$ \\
Nectandra megapotamica - Lauraceae & 13 & 86.7 & $24.7 \pm 0.85$ \\
Diospyros kaki L. - Ebenaceae & 13 & 86.7 & $25.5 \pm 0.80$ \\
Schefflera arboricola - Araliaceae & 15 & 100.0 & $24.8 \pm 0.79$ \\
Tabebuia umbellata - Bignoniaceae & 13 & 86.7 & $24.0 \pm 0.79$ \\
Citrus sinensis - Rutaceae & 15 & 100.0 & $25.0 \pm 1.03$ \\
Malus domestica - Rosaceae & 14 & 93.3 & $25.0 \pm 0.62$ \\
Ricinus communis - Euphorbiaceae & 14 & 93.3 & $25.0 \pm 0.79$ \\
Platanus acerifolia - Platanaceae & 13 & 86.7 & $24.8 \pm 1.32$ \\
\hline
\end{tabular}




\subsection{Larval stage}

The results of this study (Table 2) are very similar to those obtained for T. plagiata, which also goes through six larval instars (Temperley, 1930). The average growth ratio of 1.8 from one instar to the next, with higher values in the first three was higher than that of T. plagiata $(\sim 1.6)$ using data from Temperley (1930), and also higher than in other noctuid species with six larval instars (e.g. A. infecta $\sim 1.5$ - Teston et al. (2001), A. mahalpa $\sim 1.5$ - Specht et al. (2008)). The growth rate of our subjects approximated that of the noctuid Autoplusia egena (Guenée, 1852) ( 1.7) (Specht et al., 2007), which goes through only five larval instars and was greater than that predicted for Lepidoptera [ 1.4] (Dyar, 1890).

The observation that the larvae did not eat for up to 48 hours, resembles T. plagiata larvae, which do not eat for approximately 24 hours (Temperley, 1930). However, a longer first instar has also been reported for other representatives of Hadeninae, for instance Pseudaletia unipuncta (Haworth, 1809) (Guppy, 1961) and P. sequax (Buiainain and Silva, 1988).

The duration of the larval stage of $T$. grandirena, approximately 51 days, was similar to that observed for T. plagiata in the laboratory (Temperley (1930) and Catley (1963) 54 days). However, the period during which larvae of $T$. grandirena were active (25.3 days), in our experiment, was much shorter than that observed for T. plagiata ( $\sim 45.7$ days) by the same authors. On the other hand, the prepupal period of $T$. grandirena (Table 1) was much longer and variable than observed for T. plagiata (Temperley (1930) and Catley (1963) 8.3 days). Catley (1963) demonstrated that, in the field, even though the life cycle of $T$. plagiata is reduced to a half, the proportion of the time individuals spend in each period remains unchanged: 16 days for larval development and 4 days for the prepupal period.

The long duration of the prepupal period of $T$. grandirena (Table 1) was similar to that observed in other noctuids which overwinter on the ground in larval (prepupae) or pupae diapause, such as Xestia c-nigrum (Linnaeus, 1758) (Honĕk, 1979; Oku, 1984), Helicoverpa armigera (Hübner, [1809]) (Qureshi et al., 2000; Feng et al., 2010) and Sesamia nonagrioides (Lefebvre, 1827) (Eizaguirre et al., 2008). However, an increase in the number of larval instars was not observed for T. grandirena, contrasting with other diapausing noctuids (Esperk et al., 2007; Gadenne et al., 1997). Considering that a temperature of $25{ }^{\circ} \mathrm{C}$ used in our experiment is within the optimal range for most insects, we believe that photoperiod was involved in diapause induction, as described for several other noctuids (Qureshi et al., 2000; Feng et al., 2010). The high mortality observed in this period, despite all care taken in the experiment (Table 1) must be associated with longer duration, as observed by Eizaguirre et al. (2008), who reported very low survival rates for diapausing larvae of $S$. nonagrioides.

\subsection{Pupal stage}

The low viability of the pupal stage (Table 1), in part can be attributed to the difficulties $T$. grandirena has during the prepupal period. The pupal stage lasted nearly one quarter of the time required to complete the life cycle (Table 1) and less than the 29.7 days (28.3\%) reported for T. plagiata in the laboratory (Temperley, 1930; Catley, 1963). Our percentage is closer to that obtained for T. plagiata in the field $\sim 25 \%$ (Catley, 1963). The 13-day variation in the pupal period of $T$. grandirena (Table 1) was much higher than the range observed for $T$. plagiata (28 to 32 days) (Temperley, 1930). This variation may be an indication that T. grandirena may undergo pupal diapause under specific conditions, like other noctuids, such as H. armigera (Qureshi et al., 2000). Further studies are needed to confirm this hypothesis.

The lack of sexual dimorphism (Table 3) in the pupae is based on insufficient and very variable data, a result of the variation in the duration of the prepupal period, which gave rise to very small pupae. Additional studies should be conducted in order to ascertain possible dimorphisms, because in Hadeninae, for instance $P$. sequax, female pupae are significantly larger than male pupae (Buainain and Silva, 1988).

\subsection{Adult stage}

The average lifespan of $T$. grandirena females (Table 1) was very similar to that obtained for unfertilized females of T. plagiata (Temperley, 1930). The number of eggs obtained from the female of $T$. grandirena collected in the field was most similar to that obtained for T. grandirena $(\mathrm{n}=2.398)$ (Temperley, 1930). Similarly to what has been described for T. plagiata in the laboratory (Temperley, 1930; Catley, 1963), T. grandirena eggs were laid in batches, sometimes in layers. This contrasts with field observations of T. plagiata individuals (Weddell, 1930), which distributed their eggs throughout the plant.

\subsection{Larval development on several host plants}

The results of the larval development on several hosts indicate that larvae of $T$. grandirena can feed indiscriminately on different groups of plants without having their development affected. Such information, combined with previous records of host plants (Bruner et al., 1945; Specht et al., 2004; Janzen and Hallwachs, 2009) indicates that $T$. grandirena is highly polyphagous, like $T$. plagiata (Weddell, 1930; Szent-Ivany, 1956, 1961; SzentIvany and Catley, 1960; Catley, 1963; Dun, 1967; Hassan, 1972; Baker, 1974; Room and Smith, 1975; Ooi 1982).

The third experiment, in which the plants were exchanged every 48 hours, demonstrated that $T$. grandirena larvae can easily take on different host plants during development, as described for T. plagiata. Larvae of the latter usually start out on more attractive native or cultivated host plants and then migrate to more economically important hosts such as banana, cocoa, coffee and cassava (Weddell, 1930; Catley, 1962, 1963; Dun, 1967; Hassan, 1972; Baker, 1974; Room and Smith, 1975; Ooi 1982). 
According to Bernarys and Singer (2002), polyphagy may occur at the species, population or individual levels. Consequently, the term polyphagous, as applied to a species of herbivorous insect, does not necessary imply that an individual of that species will have a polyphagous habit. Our study showed that $T$. grandirena is polyphagous at all levels. This high degree of polyphagy makes $T$. grandirena and T. plagiata very interesting species for studies that evaluate different feeding patterns (Janzen, 2003), foraging tactics (Singer and Stireman, 2001; Bernarys and Singer, 2002) and differences in the gut microbiota (Sittenfeld et al., 2002).

The similarities of the results obtained by us with those described for the eastern T. plagiata (Weddell, 1930; Szent-Ivany, 1956, 1961; Szent-Ivany and Catley, 1960; Catley, 1963; Dun, 1967; Hassan, 1972; Baker, 1974; Room and Smith, 1975; Ooi 1982), indicate that $T$. grandirena can potentially become a key pest of several crops in Brazil and other warm regions of the Americas. Although our study did not allow us to encounter natural enemies, Janzen and Hallwachs (2009) mentioned Lespesia aletiae Riley, 1879 (Tachinidae) and an unidentified species of Sarcophagidae as parasitoids of $T$. grandirena. However, it is expected that the number of natural enemies of $T$. grandirena is much higher considering that several predators are indicated for T. plagiata, such as spiders (Oxyopodidae, Salticidae), mites (Tyroglyphidae), orthopterans (Tettigoniidae), bugs (Pentatomidae, Reduviidae, Gelastocoridae), dipterans (Asilidae), hymenopterans (Vespidae, Spechidae, Formicidae), parasitoids, especially Dipterans (Tachinidae) and Hymenopterans (Braconidae, Eulophidae, Ichneumonidae) and the entomophatogenic fungus Nomuraea rileyi (Farlow) Samson (Catley, 1962).

Acknowledgements - We thank CNPq, for the following grants: "Bolsa de Auxílio Técnico Nível Superior" (Proc. $\mathrm{n}^{\circ}$ 502067/2010-1) and "Bolsa de Iniciação Científica" (Proc. $n^{\circ}$ 507413/2010-5).

\section{References}

ANGULO, AO., OLIVARES, TS. and WEIGERT, GT., 2008. Estados inmaduros de lepidópteros nóctuidos de importancia agrícola y forestal en Chile y claves para su identificación (Lepidoptera: Noctuidae). 3rd ed. Concepción: Universidad de Concepción. $154 \mathrm{p}$.

BAKER, GL., 1974. An outbreak of Tiracola plagiata (Walker) (Lepidoptera: Noctuidae) on coffee in the Western Highlands district of Papua New Guinea. Papua New Guinea Agricultural Journal, vol. 25 , no. 3-4, p. 54-58.

BECKER, VO., 2002. The Noctuoidea (Lepidoptera) from Cuba described by Herrich-Schäffer and Gundlach in the Gundlach Colletion, Havana. Revista Brasileira de Zoologia, vol. 19, no. 2, p. 349-391. http://dx.doi.org/10.1590/S0101-81752002000200006

BERNARYS, EA. and SINGER, M., 2002. Contrasted foraging tactics in two species of polyphagous caterpillars. Acta Zoologica Academiae Scientiarum Hungaricae, vol. 48, supplement 1, p. 117-135.
BRUNER, SC., SCARAMUZZA, LC. and OTERO, AR., 1945. Catálogo de los insectos que atacan a las plantas económicas de Cuba. Boletín de la Estación Experimental Agronómica, Santiago de Las Vegas - Cuba, no. 63, 246 p.

BUAINAIN, CM. and SILVA, RFP., 1988. Biologia de Pseudaletia sequax Franclemont, 1951 (Lepidoptera, Noctuidae) em trigo (Triticum aestivum L.). Anais da Sociedade Entomológica do Brasil, vol. 17, no. 2, p. 359-372.

CATLEY, A., 1962. Tiracola plagiata Walk. (Lepidoptera: Noctuidae) a serious pest of cacao in Papua. Papua New Guinea Agricultural Journal, vol. 15, no. 1-2, p. 15-22.

CATLEY, A., 1963. Observations of the biology and control of the armyworm Tiracola plagiata Walk. (Lepidoptera: Noctuidae). Papua New Guinea Agricultural Journal, vol. 15, no. 3-4, p. 105-109.

DRAUDT, M., 1924. Hadeninae. In SEITZ, A., [1919-1944]. Die Gross-Schmetterlinge der Erde. Die Gross-Schmetterlinge des Amerikanischen Faunengebietes. Stuttgart: Alfred Kernen. p. $85-171$.

DUN, GS., 1967. Cacao flush defoliating caterpillars in Papua New Guinea. Papua New Guinea Agricultural Journal, vol. 19, p. 67-71.

DYAR, HG., 1890. The number of molts of lepidopterous larvae. Psyche, vol. 5, no. 175-176, p. 420-422. http://dx.doi. org/10.1155/1890/23871

EIZAGUIRRE, M., LÓPEZ, C. and ALBAJES, RC., 2008. Factors affecting the natural duration of diapause and post-diapause development in the Mediterranean corn borer Sesamia nonagrioides (Lepidoptera: Noctuidae). Journal of Insect Physiology, vol. 54, no. 6, p. 1057-1063. PMid:18514707. http://dx.doi.org/10.1016/j. jinsphys.2008.04.011

ESPERK, T., TAMMARU, T. and NYLIN, S., 2007. Intraspecific variability in number of larval instars in insects. Journal of Economic Entomology, vol. 100, no. 3, p. 627-645. http://dx.doi. org/10.1603/0022-0493(2007)100[627:IVINOL]2.0.CO;2

FENG, H., GOULD, F., HUANG, Y., JIANG, Y. and WU, K., 2010. Modeling the population dynamics of cotton bollworm Helicoverpa armigera (Hübner) (Lepidoptera: Noctuidae) over a wide area in northern China. Ecological Modelling, vol. 221, no. 15, p. 1819-1830. http://dx.doi.org/10.1016/j.ecolmodel.2010.04.003

GADENNE, C., DUFOUR, M-C., ROSSIGNOL, F., BECARD, J. and COUILLAUD, F., 1997. Occurrence of non-stationary moults during diapause in the corn-stalk borer, Sesamia nonagrioides (Lepidoptera: Noctuidae). Journal of Insect Physiology, vol. 43, no. 5, p. 425-431. http://dx.doi.org/10.1016/S0022-1910(96)00122-9

GREENE, GL., LEPPLA, NC. and DICKERSON, WA., 1976. Velvetbean caterpillar: a rearing procedure and artificial medium. Journal of Economic Entomology, vol. 69, no. 4, p. 487-488.

GUPPY, JC., 1961. Life history and behavior of the armyworm, Pseudaletia unipuncta (Haw.) (Lepidoptera: Noctuidae), in Eastern Ontario. Canadian Entomologist, vol. 93, no. 12, p. 1141-1153. http://dx.doi.org/10.4039/Ent931141-12

HASSAN, E., 1972. Probleme der angewandten entomologie in Papua und Neu-Guinea. Anzeiger fur Schadlingskunde Pflanzenschutz Umweltschutz, vol. 45, p. 129-134.

HOFFMANN-CAMPO, CB., OLIVEIRA, EB. and MOSCARDI, F., 1985. Criação massal da lagarta da soja (Anticarsia gemmatalis). Londrina: Embrapa-CNPSO. Documentos, no. 10. 
HONĚK, A., 1979. Regulation of diapause, number of instars, and body growth in the moth species Amathes c-nigrum (Lepidoptera: Noctuidae). Entomologia Generalis, vol. 5, no. 3, p. 221-229.

JANZEN, DH. and HALLWACHS, W., 2009. Dynamic database for an inventory of the macrocaterpillar fauna, and its food plants and parasitoids, of Area de Conservacion Guanacaste (ACG), northwestern Costa Rica (nn-SRNP-nnnnn voucher codes). Available from: $<$ http://janzen.sas.upenn.edu $>$.

JANZEN, DH., 2003. How polyphagous are Costa Rican dry forest saturniid moth caterpillars? In BASSET, Y., KITCHING, R., MILLER, S. and NOVOTNY, V. (Eds). Arthropods of tropical forests: spatio-temporal dynamics and resource use in the canopy. Cambrigde: Cambridge University Press. p. 369-379.

OKU, T., 1984. Larval diapause in the spotted cutworm, Xestia c-nigrum Linné (Lepidoptera: Noctuidae). Applied Entomology and Zoology, vol. 19, no. 4, p. 483-490.

OOI, PAC., 1982. The plague caterpillars. Nature Malaysiana, vol. 7 , no. 3 , p. 14-15.

PODOLER, H. and KLEIN, M., 1978. Distance between frontal setae: a new tool for determining caterpillar instars. Journal of Natural History, vol. 12, no. 3, p. 341-347. http://dx.doi. org/10.1080/00222937800770191

POOLE, RW., 1989. Noctuidae. In: HEPPNER, JB. (Ed). Lepidopterorum Catalogus. New York: Brill. v. 2. p. 501-1013.

QURESHI, MH., MURAI, T., YOSHIDA, H. and TSUMUKI, H., 2000. Populational variation in diapause-induction and -termination of Helicoverpa armigera (Lepidoptera: Noctuidae). Applied Entomology and Zoology, vol. 35, no. 3, p. 357-360. http://dx.doi.org/10.1303/aez.2000.357

ROBINSON, GS., 1975. Macrolepidoptera of Fiji and Rotuma: a taxonomic and geographic study. Faringdon: Classey. 362 p.

ROOM, PM. and SMITH, ESC., 1975. Relative abundance and distribution of insect pests, ants and other components of the cocoa ecosystem in Papua New Guinea. Journal of Applied Ecology, vol. 12, no. 1, p. 31-46. http://dx.doi.org/10.2307/2401716

SINGER, MS. and STIREMAN, JO., 2001. How foraging tactics determine host-plant use by a polyphagous caterpillar. Oecologia, vol. 129, p. 98-105. http://dx.doi.org/10.1007/s004420100707

SITTENFELD, A., URIBE-LORIO, L., MORA, M., NIELSEN, V., ARRIETA, G. and JANZEN, DH., 2002. Does a polyphagous caterpillar have the same gut microbiota when feeding on different species of food plants? Revista de Biologia Tropical, vol. 50, no. 2, p. 547-560. PMid:12298285.
SPECHT, A. and CORSEUIL, E., 2001. Ocorrência de noctuídeos (Lepidoptera, Noctuidae) no Rio Grande do Sul, Brasil. Nota suplementar I. Biociências, vol. 9, no. 2, p. 97-103.

SPECHT, A., FORMENTINI, AC. and CORSEUIL, E., 2008. Bionomy of Anicla mahalpa Schaus, 1898 (Lepidoptera: Noctuidae: Noctuinae), in the laboratory. Brazilian Journal of Biology, vol. 68, no. 2, p. 415-418. PMid:18660973. http://dx.doi.org/10.1590/ S1519-69842008000200026

SPECHT, A., SILVA, EJE. and LINK, D., 2004. Noctuídeos (Lepidoptera, Noctuidae) do Museu Entomológico Ceslau Biezanko, Departamento de Fitossanidade, Faculdade de Agronomia "Eliseu Maciel”, Universidade Federal de Pelotas, RS. Revista Brasileira de Agrociência, vol. 10, no. 4, p. 389-409.

SPECHT, A., VOGT, TG. and CORSEUIL, E., 2007. Biological aspects of Autoplusia egena (Guenée) (Lepidoptera: Noctuidae, Plusiinae). Neotropical Entomology, vol. 36, no. 1, p. 1-4. PMid:17420856. http://dx.doi.org/10.1590/S1519566X2007000100001

SZENT-IVANY, JJH., 1956. New insect pest and host plant records in the Territory of Papua and New Guinea. Papua New Guinea Agricultural Journal, vol. 11, p. 82-87.

-, 1961. Insect pests of Theobroma cacao in the Territory of Papua and New Guinea. Papua New Guinea Agricultural Journal, vol. 13, p. $127-147$

SZENT-IVANY, JJH. and CATLEY, A., 1960. Host plant and distribution records of some insects in New Guinea and adjacent Islands. Pacific Insects, vol. 2, no. 3, p. 255-261.

TEMPERLEY, ME., 1930. Life history notes on the banana fruit-eating caterpillar (Tiracola plagiata Walk.). Queensland Agricultural Journal, vol. 33, p. 251-261.

TESTON, JA., SPECHT, A. and CORSEUIL, E., 2001. Biology of Anicla infecta (Ochsenheimer, 1816) (Lepidoptera, Noctuidae, Noctuinae), under laboratory condictions. Brazilian Journal of Biology, vol. 61, no. 4, p. 661-666. PMid:12071323.

TOOD, EL. and POOLE, RW., 1980. The American species of the Tiracola plagiata Walker complex (Lepidoptera: Noctuidae: Hadeninae). Proceedings of the Entomological Society of Washington, vol. 82 , no. 3, p. 396-400.

WEDDELL, JA., 1930. Field notes on the banana fruit-eating caterpillar (Tiracola plagiata Walk.). Queensland Agricultural Journal, vol. 33, p. 186-201. 